Old Dominion University

ODU Digital Commons

\title{
Partnering Undergraduate Engineering Students With Preservice Teachers to Design and Teach an Elementary Engineering Lesson Through Ed+gineering
}

\author{
Kristie Gutierrez \\ Old Dominion University, kgutierr@odu.edu \\ Stacie I. Ringleb \\ Old Dominion University, sringleb@odu.edu \\ Jennifer Jill Kidd \\ Old Dominion University, jkidd@odu.edu \\ Orlando M. Ayala \\ Old Dominion University, oayala@odu.edu \\ Pilar Pazos \\ Old Dominion University, mpazosla@odu.edu
}

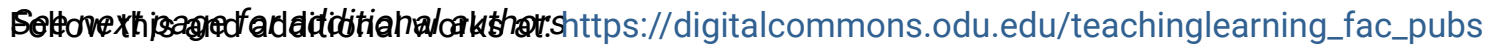

Part of the Engineering Education Commons, Mechanical Engineering Commons, and the Teacher Education and Professional Development Commons
\end{abstract}

\section{Original Publication Citation}

Gutierrez, K., Ringleb, S., Kidd, J., Ayala, O., Pazos, P., \& Kaipa, K. (2020). Partnering undergraduate engineering students with preservice teachers to design and teach an elementary engineering lesson through Ed+gineering. 2020 ASEE Virtual Annual Conference Content Access, Virtual On Line, June 22-26, 2020.

This Conference Paper is brought to you for free and open access by the Teaching \& Learning at ODU Digital Commons. It has been accepted for inclusion in Teaching \& Learning Faculty Publications by an authorized administrator of ODU Digital Commons. For more information, please contact digitalcommons@odu.edu. 


\section{Authors}

Kristie Gutierrez, Stacie I. Ringleb, Jennifer Jill Kidd, Orlando M. Ayala, Pilar Pazos, and Krishnanand Kaipa 


\section{Partnering Undergraduate Engineering Students with Preservice Teachers to Design and Teach an Elementary Engineering Lesson through Ed+gineering}

\section{Dr. Kristie Gutierrez, Old Dominion University}

Dr. Gutierrez received her B.S. in Biology from the University of North Carolina at Chapel Hill in 2001, M.Ed. in Secondary Science Education in 2005 from the University of North Carolina at Wilmington, and Ph.D. in Science Education in 2016 from North Carolina State University. Dr. Gutierrez is currently serving as an Assistant Professor of Science Education in the Department of Teaching and Learning at Old Dominion University. She teaches elementary science methods and secondary science and mathematics methods courses with emphasis on multicultural education and equity pedagogies. Her research interests include both formal and informal STEM education, with specialization in the integration of engineering and computer science into science education through preservice and inservice educator development.

\section{Dr. Stacie I Ringleb, Old Dominion University}

Stacie Ringleb is an associate professor in the Department of Mechanical and Aerospace Engineering at Old Dominion University. Dr. Ringleb received a B.S. in biomedical engineering from Case Western Reserve University in 1997, a M.S.E. from Temple University in Mechanical Engineering in 1999, and a PhD from Drexel University in Mechanical Engineering in 2003. She completed a post-doctoral fellowship in the Orthopedic Biomechanics Lab at the Mayo Clinic. Dr. Ringleb research interests include, biomechanics and rehabilitation engineering as well as multi-disciplinary approaches to improving engineering education.

\section{Dr. Jennifer Jill Kidd, Old Dominion University}

Dr. Jennifer Kidd is a Senior Lecturer in the Department of Teaching and Learning at Old Dominion University. Her research interests include engineering education, computational thinking, student-authored digital content, classroom assessment, especially peer review, and diversity issues. She currently has support from the National Science Foundation for two projects related to engineering education for preservice teachers.

\section{Dr. Orlando M Ayala, Old Dominion University}

Dr. Ayala received his BS in Mechanical Engineering with honors (Cum Laude) from Universidad de Oriente (Venezuela) in 1995, MS in Mechanical Engineering in 2001 and PhD in Mechanical Engineering in 2005, both from University of Delaware (USA). Dr. Ayala is currently serving as Assistant Professor of Mechanical Engineering Technology Department, Frank Batten College of Engineering and Technology, Old Dominion University, Norfolk, VA.

Prior to joining ODU in 2013, Dr. Ayala spent three years as a Postdoctoral Researcher at University of Delaware where he expanded his knowledge on simulation of multiphase flows while acquiring skills in high performance parallel computing and scientific computation. Before that, Dr. Ayala hold a faculty position at Universidad de Oriente at Mechanical Engineering Department where he taught and developed graduate and undergraduate courses for a number of subjects such as Fluid Mechanics, Heat Transfer, Thermodynamics, Multiphase Flows, Fluid Mechanics and Hydraulic Machinery, as well as Mechanical Engineering Laboratory courses.

In addition, Dr. Ayala has had the opportunity to work for a number of engineering consulting companies, which have given him an important perspective and exposure to industry. He has been directly involved in at least 20 different engineering projects related to a wide range of industries from petroleum and natural gas industry to brewing and newspaper industries. Dr. Ayala has provided service to professional organizations such as ASME. Since 2008 he has been a member of the Committee of Spanish Translation of ASME Codes and the ASME Subcommittee on Piping and Pipelines in Spanish. Under both memberships the following Codes have been translated: ASME B31.3, ASME B31.8S, ASME B31Q and ASME BPV Sections I. 
While maintaining his industrial work active, his research activities have also been very active; Dr. Ayala has published 90 journal and peer-reviewed conference papers. His work has been presented in several international forums in Austria, USA, Venezuela, Japan, France, Mexico, and Argentina. Dr. Ayala has an average citation per year of all his published work of 44.2

\section{Dr. Pilar Pazos, Old Dominion University}

Pilar Pazos is an Associate Professor in the Department of Engineering Management and Systems Engineering at Old Dominion University, Norfolk, VA, USA. Her main areas of research interest are collaborative work-structures, virtual teams and team decision-making and performance.

\section{Dr. Krishnanand Kaipa, Old Dominion University}




\title{
Partnering Undergraduate Engineering Students with Preservice Teachers to Design and Teach an Elementary Engineering Lesson through Ed+gineering
}

\begin{abstract}
Major challenges in engineering education include retention of undergraduate engineering students (UESs) and continued engagement after the first year when concepts increase in difficulty. Additionally, employers, as well as ABET, look for students to demonstrate non-technical skills, including the ability to work successfully in groups, the ability to communicate both within and outside their discipline, and the ability to find information that will help them solve problems and contribute to lifelong learning. Teacher education is also facing challenges given the recent incorporation of engineering practices and core ideas into the Next Generation Science Standards (NGSS) and state level standards of learning. To help teachers meet these standards in their classrooms, education courses for preservice teachers (PSTs) must provide resources and opportunities to increase science and engineering knowledge, and the associated pedagogies. To address these challenges, Ed+gineering, an NSF-funded multidisciplinary collaborative service learning project, was implemented into two sets of pairedclasses in engineering and education: a 100 level mechanical engineering class $(n=42)$ and a foundations class in education $(n=17)$, and a fluid mechanics class in mechanical engineering technology $(n=23)$ and a science methods class $(n=15)$. The paired classes collaborated in multidisciplinary teams of 5-8 undergraduate students to plan and teach engineering lessons to local elementary school students. Teams completed a series of previously tested, scaffolded activities to guide their collaboration. Designing and delivering lessons engaged university students in collaborative processes that promoted social learning, including researching and planning, peer mentoring, teaching and receiving feedback, and reflecting and revising their engineering lesson.
\end{abstract}

The research questions examined in this pilot, mixed-methods research study include: (1) How did PSTs' Ed+gineering experiences influence their engineering and science knowledge?; (2) How did PSTs' and UESs' Ed+gineering experiences influence their pedagogical understanding?; and (3) What were PSTs' and UESs' overall perceptions of their Ed+gineering experiences? Both quantitative (e.g., Engineering Design Process assessment, Science Content Knowledge assessment) and qualitative (student reflections) data were used to assess knowledge gains and project perceptions following the semester-long intervention. Findings suggest that the PSTs were more aware and comfortable with the engineering field following lesson development and delivery, and often better able to explain particular science/engineering concepts. Both PSTs and UESs, but especially the latter, came to realize the importance of planning and preparing lessons to be taught to an audience. UESs reported greater appreciation for the work of educators. PSTs and UESs expressed how they learned to work in groups with multidisciplinary 
members, a valued skill in both professions. Yearly, the Ed+gineering research team will also request and review student retention reports in their respective programs to assess project impact.

\section{Introduction}

This research paper addresses major challenges in engineering education including retention of undergraduate engineering students (UESs) [1] and continued engagement after the first year when concepts increase in difficulty. Additionally, employers, as well as the Accrediting Board for Engineering and Technology [ABET] expect students to demonstrate disciplinary expertise and non-technical skills, including the ability to work successfully in groups, the ability to communicate with a range of audiences, and the ability to find information that can solve problems and contribute to lifelong learning [2].

A consistent concern in engineering education is retention and attrition. Santiago and Henzel [1] found that the top reasons why students leave engineering programs in their first or second years were content difficulty, effort required to be successful, and content that did not match their interests. Strategies to help combat retention and attrition problems include providing more relevance of course content to students' lives, incorporating more active learning strategies into assignments and instructional approaches, and exposing tangible outcomes for their learning efforts. Researchers (e.g., [3]-[4]) have introduced service-learning projects and collaborative learning as ways in which to retain engineers in their academic programs and into their first years post-academia. A recent study showed positive effects of service learning on the retention of engineering students, especially among underrepresented groups who demonstrated more motivation to persist in their programs and interest in helping others in the profession [5]. Additional research indicates retention as one of the main benefits of implementing servicelearning in engineering programs [6]. The current pilot study aims to use service-learning and multidisciplinary collaboration as a way to retain engineering students and professionals in the engineering field. It is important to note that while our current research questions and data do not specifically address the areas of retention and attrition in this study, the data provided here sets the stage for the longitudinal research design of the Ed+gineering project with these areas as main foci for engineers within our program and as emerging engineering professionals.

Teacher education is also facing challenges given the recent incorporation of engineering practices and core ideas into the Next Generation Science Standards (NGSS) [7] and individual states' standards of learning at the elementary school level. There is an urgent need to prepare elementary preservice teachers (PSTs) to confidently and competently teach engineering content [8]. Steinberg, Wyner, Borman, and Salame [9] explain that elementary preservice teachers flourish if they are exposed to, and learn, content that is directly relevant to the science [and engineering] standards that they will teach in their own future classrooms. In fact, the authors found that the courses that are the "most successful at improving student understanding of science $[\ldots]$ are well matched to the needs of the intended audience" (p. 51). However, PK-6 
teachers' lack of exposure to engineering in their coursework and lack of confidence in the underlying disciplines of math and science may be contributing factors as to why engineering is the least developed subject area in STEM [10]-[11]. Thus, education courses for PSTs should provide resources and opportunities to increase science and engineering knowledge, and associated pedagogies to help address the needs of elementary teachers and their students.

Hsu et al. [11] found that while elementary school teachers believed that it was important to incorporate engineering into their curricula, they did not feel confident to teach the concepts. A possible solution is to have PSTs implement engineering lessons in a supported and low-risk context. This strategy was found to be a powerful mediator of self-efficacy in a recent study with in-service teachers [12]. One means to provide a supportive environment is to partner PSTs with engineering students as they develop lessons. One study found that education and engineering students both benefitted when they collaboratively planned robotics activities for early childhood students [13]. PSTs were able to see the potential of robotics to engage their students and could design applications with the safety net of collaborating engineering students. Engineering students benefited from an authentic engineering experience where they had to communicate with, and meet the expectations of, a non-technical client (their partner PSTs). Successful experiences like these increase the likelihood that teachers implement additional engineering lessons [12]. The two-way exchange of information between engineers and educators has been found to increase the appreciation of engineers and engineering concepts by educators, and "engineers recognize that teachers are engaged in establishing long-term pedagogical relationships in the classroom" [14].

Ed+gineering is a multidisciplinary service-learning collaboration that helps UESs and PSTs address their respective challenges by working together. This partnership allows college students to learn engineering practices by using the engineering design process to design and implement engineering lessons that teach elementary school students about specific science and engineering concepts. The college student interactions in this project strive to enhance understanding through reciprocal learning. Engineering students teach education students about engineering concepts, while education students teach engineering students about teaching and communicating with non-technical audiences. Working together, both groups of students engage PK-6 students in engineering design lessons. This paper reports on the pilot year of Ed+gineering, a novel multidisciplinary partnership in which preservice teachers (PSTs) and undergraduate engineering students (UESs) collaboratively planned, developed, and delivered engineering lessons to upper-elementary school students as a course assignment in multiple required college courses in their respective academic programs.

\section{Theoretical Framework}

Ed+gineering draws on social constructivism [15]-[16]. According to this theory, multidisciplinary collaboration prompts students to experience new and different perspectives as 
they build knowledge [15]. The collaboration between PSTs and UESs provides an ideal opportunity for peer learning [17], both through knowledge exchange (e.g., engineering students explain basic technical concepts and PSTs share pedagogical approaches) and group problem solving (e.g., groups work together to design a viable lesson). Designing and delivering lessons engages students in collaborative processes that promote social learning including researching and planning, peer mentoring, teaching and receiving feedback, and reflecting and revising their engineering lesson. Constructivism also informs lesson development through the $5 \mathrm{E}$ instructional model [18]. This inquiry-based instructional approach to lesson preparation provides the foundation for engineering design challenges. This constructivist framework provides PSTs and UESs a collaborative space in which to co-construct innovative engineering challenges for upper-elementary students. Specifically, this paper focuses on Ed+gineering's implementation in two education courses and two engineering courses during Spring 2019: Collaboration 1, during PSTs' and UESs' first courses in education and engineering, respectively, and Collaboration 2, during an elementary science methods course and a fluid mechanics course near the end of education and engineering students' respective programs.

\section{Research Questions}

1. How did PSTs' Ed+gineering experiences influence their engineering and science knowledge?

2. How did PSTs' and UESs' Ed+gineering experiences influence their pedagogical understanding?

3. What were PSTs' and UESs' overall perceptions of their Ed+gineering experiences?

\section{Methods}

Collaboration 1 occurred in the context of an educational foundations course $(n=17)$ and consisted of a partnership with introductory mechanical engineering students $(n=42)$. Collaboration 2 was implemented in an elementary science methods course $(n=15)$ near the end of the PSTs' academic preparation and were partnered with fluid mechanics students $(n=23)$. In both collaborations, multidisciplinary teams of 5-10 students were formed using the CATME (https://info.catme.org/) Team Maker tool in order to reduce bias in team formation. These teams developed inclusive engineering lessons throughout the semester and taught their engineering lessons to visiting elementary students. Teams completed a series of previously tested, scaffolded activities to guide their collaboration and their multidisciplinary teamwork tasks [19]. The engineering lessons followed the 5E instructional model [18], slightly modified to incorporate the engineering design process (EDP). Each multidisciplinary team received written feedback throughout the lesson planning process. Additionally, each team taught their lesson to a peer group, and experts in education and engineering, through a "dress rehearsal" prior to actually facilitating their engineering lesson with elementary students. 
Local 4th and 5th grade students traveled to the university campus for Engineering Day where they toured engineering labs and a dorm room, ate lunch at the university dining hall, and participated in the engineering lessons developed and led by the university student teams. Many of the elementary students who participated were from racioethnic demographic subgroups (i.e., persons of color) who have been traditionally underrepresented in STEM subject areas. The visiting students attended Title I schools (e.g., children from low income families comprise at least $40 \%$ of the student body) and many will be first generation college students. Thus, it was important that the engineering lesson plans explicitly included representation from diverse (e.g., females, people of color) engineering professionals.

In Collaboration 1, university students were free to choose from a variety of engineering technologies in which to create design challenges for the elementary students including race cars, planes, parachutes, and simple machines. However, in Collaboration 2, university students' challenge options were constrained to engineering topics that aligned with scientific concepts (e.g., density, forces, viscosity, buoyancy) covered in fluid mechanics and that also aligned with state standards for 4th grade elementary students. Each lesson was planned to span an hour, to follow the 5E instructional model (Engage, Explore, Explain, Elaborate, Evaluate) and to incorporate the Engineering Design Process (Define the Problem, Brainstorm, Plan, Build, Test, Re-design). Elementary students were led through these inquiry-based lessons, where successes and failures were equally valued as part of the learning process. Following Engineering Day, ODU students reflected on the elementary students' visit, their multidisciplinary team collaboration, and their overall perceptions of the Ed+gineering project.

\section{Data Sources}

\section{Quantitative}

Collaboration 1: In this intervention, engineering and science knowledge was defined as understanding of the engineering design process (EDP). After scouring the literature and finding no appropriate quantitative instruments to measure the PSTs' and UESs' understanding of the design process (e.g. brainstorming, prototyping, iteration, and constraints), the research team designed their own using a compilation of instruments. The researchers adapted items from measures created by two organizations focused on K-12 engineering education, Engineering is Elementary and TeachEngineering, to form 15 engineering scenarios that could be answered through selected response items. The survey also included one short response item adapted from an instrument Hsu, Cardella, \& Purzer [20] developed to assess elementary students' knowledge of the engineering design process. The question asked how a design process could be improved. Answers that referred to any part of the engineering design process were counted as correct. 
Collaboration 2: Basic concepts addressed in Fluid Mechanics (e.g. drag, lift, viscosity, forces, friction, density) are included in the elementary school standards (e.g., NGSS, state standards) and were defined as the engineering and science knowledge for this intervention. Questions ( $n=$ 50) related to the science concepts identified above were compiled from various established instruments (e.g., state standards, TIMSS, Physical Science Concept Inventory, MOSART). Both PSTs and UESs in this collaboration completed the instrument at the beginning and end of the semester.

\section{Qualitative}

Collaborations $1 \& 2$ : Following lesson design and delivery, each student independently completed a lesson reflection of approximately 40 short-answer questions. A subset of reflection questions was open-coded using emergent themes through thematic coding by two independent coders. Any coding discrepancies were negotiated by the co-coders at $100 \%$ agreement.

\section{Findings and Discussion}

\section{RQ1: PSTs' Engineering and Science Knowledge}

\section{Collaboration 1}

Preliminary analyses of post-test scores suggest that there were significant differences between the UESs and PSTs $(t(28)=3.53, p=0.001)$. On the post-test, the UESs $(n=19)$ averaged approximately 2.6 points higher than the PSTs $(n=11)(12.8$ vs. 10.2, respectively, out of 16 possible points). Both groups of undergraduate students demonstrated a basic understanding of EDP as almost all students recognized that many correct solutions can exist for engineering design problems and that engineers do not go through the design process just once. Both groups showed similar trends in incorrect responses. Two commonly missed questions related to the purpose of brainstorming. Neither group understood that brainstorming should focus on quantity, rather than quality, of ideas. An item missed by more than half of the students revealed that students did not understand that the "engineering design loop" could occur in any direction and include shortcuts. UESs were more adept than PSTs at aligning descriptions of activities with particular stages in the EDP. Analysis of the PST reflections (see Table I) suggests that many of the PSTs who participated in Collaboration 1 were able to explain the science concepts they taught and explain how the science concepts related to the engineering design challenges presented to the elementary students. 
TABLE I

PSTs' ACTUAL SCIENCE \& ENGINEERING UNDERSTANDING

\begin{tabular}{|c|c|c|c|}
\hline Theme & \multicolumn{2}{|c|}{$\begin{array}{l}\text { Theme } \\
\text { Frequency } \\
\text { (total \# of instances) }\end{array}$} & $\begin{array}{c}\text { Dominant Sub-Themes } \\
\text { (if applicable) } \\
\text { Frequencies ( } n=\# \text { of coded instances) and Exemplar Quotes }\end{array}$ \\
\hline RQ1-Collab 1 & PSTs & UESs & \multirow[b]{2}{*}{$\begin{array}{l}\text { Engineering Practices or Principles } \\
\text { PST: } n=2 ; \text { After they tested them, we gave our lesson on the topic and had them remake } \\
\text { their planes and test them again to see if they were able to make changes to help them go } \\
\text { further...The students were able to build their own parachutes, see how it worked, and what } \\
\text { they could do to change it. } \\
\text { Science Concepts } \\
\text { PST: } n=11 ; \text { One concept we taught to them was about air resistance. We had them hold out } \\
\text { their hands flat and move them back and forth to feel how much air was pushing against } \\
\text { them. Then we had them do the same but with their hands up to feel the difference. We } \\
\text { explained to them that the reason you feel more air against your hand one way than the } \\
\text { other is because of air resistance. The less surface space there is in an object the easier it } \\
\text { will move through the air. } \\
\text { Connections Between Science \& Engineering } \\
\text { PST: } n=34 ; \text { Weight and Balance kept the planes from going sideways while airborne. Lift } \\
\text { expressed how the air in the room travelled under the planes to allow them to remain in } \\
\text { flight while drag incorporated forces pushing down onto the plane. Thrust, although } \\
\text { typically in engines, showed itself in the form of how much force was utilized when tossing } \\
\text { the planes. }\end{array}$} \\
\hline $\begin{array}{l}\text { PSTs' Actual } \\
\text { Science \& } \\
\text { Engineering } \\
\text { Understanding }\end{array}$ & 47 & $\begin{array}{l}\text { UES data } \\
\text { was not } \\
\text { analyzed } \\
\text { for this } \\
\text { category } \\
\text { because it } \\
\text { did not } \\
\text { align with } \\
\text { the } \\
\text { identified } \\
\text { research } \\
\text { questions }\end{array}$ & \\
\hline
\end{tabular}




\begin{tabular}{|c|c|c|c|}
\hline RQ1-Collab 2 & PSTs & UESs & $\begin{array}{l}\text { Engineering Practices \& Principles } \\
\cdot \quad \text { Engineering Explained Adequately Well }\end{array}$ \\
\hline $\begin{array}{l}\text { PSTs' Actual } \\
\text { Science \& } \\
\text { Engineering } \\
\text { Understanding }\end{array}$ & 24 & $\begin{array}{l}\text { UES data } \\
\text { was not } \\
\text { analyzed } \\
\text { for this } \\
\text { category } \\
\text { because it } \\
\text { did not } \\
\text { align with } \\
\text { the } \\
\text { identified } \\
\text { research } \\
\text { questions }\end{array}$ & $\begin{array}{l}\text { includes five different stages. Stage one (ASK): this is where the engineer would define } \\
\text { the problem. } \\
\text { Engineering Correct but not Thoroughly Explained } \\
\text { PST: } n=1 ; \text { I learned about thrust and pressure. I learned that pressure in designing } \\
\text { tanks, pipes etc. engineers must consider pressure. Pressure is the reason why ships can } \\
\text { travel on water. } \\
\text { Engineering Explained Poorly } \\
\text { PST: } n=0 ; \text { n/a } \\
\text { Science Concepts } \\
\text { Science Explained Adequately Well } \\
\text { PST: } n=6 ; \text {... kinetic friction was when an object was in motion or moving around. For } \\
\text { example, this could be a moving car on the road, or someone swinging on a swing. We } \\
\text { also taught them about static friction where an object is in rest. For example, books } \\
\text { sitting on a table or a person standing still. } \\
\text { Science Correct but not Thoroughly Explained } \\
\text { PST: } n=4 ; \text {...viscosity was how thick or thin a substance is. } \\
\text { Science Explained Poorly } \\
\text { PST: } n=5 ; \text { Density in my terms is the volume mass of an object. } \\
\text { Connections Between Science \& Engineering } \\
\text { Science \& Engineering Explained Adequately Well } \\
\text { PST: } n=3 ; \text { I understand that drag is a force that causes resistance of an object. Lift is a }\end{array}$ \\
\hline
\end{tabular}




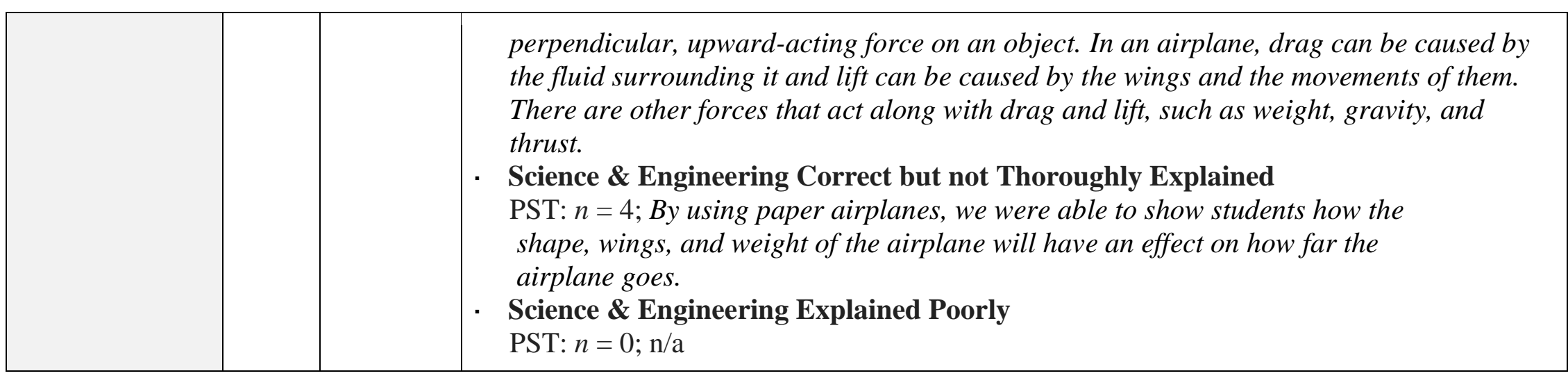

Table I provides exemplars of PSTs' science \& engineering understanding following participation in the Ed+gineering Project through frequency counts and exemplar quotes for Collaborations (Collab) 1 and 2. 


\section{Collaboration 2}

Prior to and following the collaboration, ANOVAs indicated that there were significant differences in overall science content knowledge on the science content test based on the course (education or engineering) $(F(2,36)=16.63, p<0.001)$. This data from engineering and education students served a baseline by which to compare the two student sub-populations, and to compare growth in content knowledge from pre- to post-project participation. Prior to the Ed+gineering experience, students in the fluid mechanics engineering course scored significantly higher on the science content test overall. Following the collaboration, the differences were still significant $(F(2,30)=10.75, p<0.01)$.

Out of 50 total questions on the science content test, paired $t$-tests indicated that for all students, there were 8 questions that showed significant improvement; for education students there were 7 questions that showed significant improvement; and for UESs there were 2 questions that showed significant improvement. In paired $t$-tests of the 9 unique constructs, all students showed significant positive growth in the viscosity construct (pre: $M=3.06, S D=1.13$; post: $M=3.44, S D=1.27), t(31)=1.71, p<0.05$; and the conservation of energy/friction construct (pre: $M=2.78, S D=1.18$; post: $M=3.19, S D=1.12$ ), $t(31)=1.71, p<0.05$. Education students showed positive growth in conservation of energy/friction construct (pre: $M=$ 2.20, $S D=0.86$; post: $M=2.80, S D=1.01), t(14)=1.87, p<0.05$; and the drag \& lift construct (pre: $M=2.33, S D=1.35$; post: $M=3.20, S D=1.21$ ), $t(14)=2.83, p<0.01$. UESs scored higher pre- and post- on all of the science constructs overall and thus, there were no specific constructs that improved significantly. Finally, only the education students' overall science content scores improved from pre- to post- administration (pre: $M=25.5, S D=6.16$; post: $M=$ $27.9, S D=6.55), t(14)=1.89, p<0.05$. Analysis of the PST reflections (see Table I) suggests Collaboration 2 resulted in an increase in science content knowledge for PSTs.

\section{RQ2: PSTs' and UESs'pedagogical understanding}

Table II describes student reflection comments related to the pedagogical understanding of all students in Collaborations $1 \& 2$. In Collaboration 2 (science methods), PSTs focused on pedagogy in their course throughout the semester; thus, it is not surprising that they reported growth in pedagogical understanding much more frequently than the PSTs in Collaboration 1. Additionally, UESs also reported gains in their pedagogical content knowledge, which is also not surprising, as this is a novel area for most engineering students. PSTs and UESs in Collaborations $1 \& 2$ most often shared their thoughts about Teaching and Interacting with Kids and Planning Lessons and Preparing, while students in Collaboration 2 additionally referenced their growth in Inquiry/the 5E Model. PSTs more often noted the STEM focus in schools/curriculum and Classroom Management as compared to UESs who were especially concerned with Age Appropriateness and Classroom Management. 


\section{TABLE II}

\section{PERCEPTIONS OF CHANGE IN PEDAGOGICAL UNDERSTANDING}

\begin{tabular}{|c|c|c|c|}
\hline Theme & \multicolumn{2}{|c|}{$\begin{array}{l}\text { Theme } \\
\text { Frequency } \\
\text { (total \# of } \\
\text { instances) }\end{array}$} & $\begin{array}{c}\text { Dominant Sub-Themes } \\
\text { (if applicable) } \\
\text { Frequencies ( } n=\# \text { of coded instances) and Exemplar Quotes }\end{array}$ \\
\hline RQ2-Collab 1 & PSTs & UESs & \multirow[b]{2}{*}{$\begin{array}{l}\text { Understanding Students' Prior Knowledge \& Age Appropriateness } \\
\text { PST: } n=1 ; \text { All the students had so many questions, but they were all different. I believe } \\
\text { that this is because they saw our lesson in a different way, which I thought was pretty } \\
\text { cool. } \\
\text { UES: } n=5 ; \text { I also learned that comprehensive teaching is more difficult when you don't } \\
\text { know your audience's general knowledge. Even the basics can be confusing to some and } \\
\text { it is important to be able to think on the spot. One example of this was our direction to } \\
\text { assume all students knew how to make a basic paper airplane. When we were } \\
\text { presenting, we found that only } 2 \text { of our } 7 \text { students had ever tried } \\
\text { to make one or had any idea of what to do. We had to change our lesson completely on } \\
\text { the spot in order to appeal to the actual skillset of our students } \\
\text { Teaching \& Interacting with Kids } \\
\text { PST: } n=16 ; \text { The most valuable bit of knowledge I learned from this lesson is if } \\
\text { something doesn't go as you planned you can't let it get you flustered, you must } \\
\text { continue with the lesson even if something is forgotten, or if something goes wrong. The } \\
\text { show must go on } \\
\text { UES: } n=6 ; \text { I learned that to be a teacher you have to be patient with our students. } \\
\text { STEM Focus } \\
\text { PST: } n=1 ; \text { My understanding of engineering as a field has changed significantly as a } \\
\text { result of this project because I was able to learn about the different activities } \\
\text { engineering can consist of and how I can actually integrate engineering with other } \\
\text { subjects and lessons. } \\
\text { UES: } n=0 ; \text { n/a }\end{array}$} \\
\hline $\begin{array}{l}\text { Perceptions of Change } \\
\text { in Pedagogical } \\
\text { Understanding }\end{array}$ & 31 & 25 & \\
\hline
\end{tabular}




\begin{tabular}{|c|c|c|c|}
\hline & & & $\begin{array}{l}\text { Planning Lesson \& Preparing } \\
\text { PST: } n=11 ; \text { I learned a lot about creating a lesson plan and that it is okay not to stick } \\
\text { to the plan. You have to adjust to the needs of your students and what works best for } \\
\text { them. } \\
\text { UES: } n=11 ; \text { I did not know how much goes into teaching a course until this project. It } \\
\text { takes a lot of planning. } \\
\text { Inquiry \& Hands-on Instruction/5E Model for Inquiry } \\
\text { PST: } n=1 ; \text { Knowing that they would want to be taught this in their school was very eye } \\
\text { opening for me. With teaching, I learned that students want to be more hands on. } \\
\text { UES: } n=0 ; n \text { a } \\
\text { Classroom Management } \\
\text { PST: } n=1 ; \text { It taught us what a classroom environment is actually like, and we can use } \\
\text { the experience to better improve our abilities as instructors. } \\
\text { UES: } n=3 ; \text { What I learned about teaching was you have to be able to engage your } \\
\text { students and then be able to keep them on track. If unable to keep them on track students } \\
\text { could become easily distracted and then it is harder for the teacher to teach their lesson. }\end{array}$ \\
\hline RQ2- Collab 2 & PSTs & UESs & \multirow{2}{*}{$\begin{array}{l}\text { Understanding Students' Prior Knowledge \& Age Appropriateness } \\
\text { PST: } n=8 ; \text { Engineering and Education majors have vastly different mindsets and } \\
\text { approaches to communicating information to children. While most teachers readily } \\
\text { grasp that you have to explain things to students on a level that matches the world they } \\
\text { observe, the engineers tended to often lose track of who their audience was. } \\
\text { UES: } n=2 ; \text { I have taught before and I guess would say that teaching is a bit different } \\
\text { from } 4 \text { th graders to adults. } \\
\text { Teaching \& Interacting with Kids } \\
\text { PST: } n=6 ; \text { The most valuable thing about this experience was seriously the students! } \\
\text { They warmed my heart just watching them enjoy the project and wanting to learn about } \\
\text { engineering. } \\
\text { UES: } n=7 ; \text { I learned more about teaching than anything else, interacting with students } \\
\text { is the biggest way to help them comprehend information. }\end{array}$} \\
\hline $\begin{array}{l}\text { Perceptions of Change } \\
\text { in Pedagogical } \\
\text { Understanding }\end{array}$ & 50 & 35 & \\
\hline
\end{tabular}




\begin{tabular}{|c|c|c|}
\hline & & $\begin{array}{l}\text { STEM Focus } \\
\text { PST: } n=6 ; \text { I found that this project was useful because engineering is going to be } \\
\text { implemented in [our state's] standards soon. } \\
\text { UES: } n=0 ; \text { n/a } \\
\text { Planning Lesson \& Preparing } \\
\text { PST: } n=14 ; \text { I learned that teaching requires patience and it is important to practice } \\
\text { your lesson plan before you teach it. The more you practice the lesson the less flaws you } \\
\text { will have. } \\
\text { UES: } n=14 ; \text { I learned that you could break down engineering to a level that a child } \\
\text { could understand it. Just is the matter of how you do is a just a big factor and make it } \\
\text { enjoyable in the process. I learned that a teacher planning has to be very detailed and } \\
\text { making the subject manner very interesting. } \\
\text { Inquiry \& Hands-on Instruction/5E Model for Inquiry } \\
\text { PST: } n=12 ; \text { Students need to be given a chance to explore their thinking, try the } \\
\text { experiment out first and then document the results. Using an inquiry-based learning, } \\
\text { teachers are facilitators. We are supposed to generate questions that would challenge } \\
\text { the minds of our students and allow them to think on their own. } \\
\text { UES: } n=6 ; \text { On the teaching aspect I think the five Es is what taught me the most. Using } \\
\text { that method in that order really requires the students to interact which I believe is the } \\
\text { best way to learn. } \\
\text { Classroom Management } \\
\text { PST: } n=3 ; \text { I learned that I can manage of class about } 20 \text { students, and that teaching is } \\
\text { still the profession for me! } \\
\text { UES: } n=6 ; \text { learned how tough teaching can be. Teachers have to change up their } \\
\text { lesson plans if something unexpected shows up or they would fall behind. Also having to } \\
\text { worry about what the kids might do when you are working with them can be kind of } \\
\text { stressful. }\end{array}$ \\
\hline
\end{tabular}

Table II provides exemplars of the perceptions of change in pedagogical understanding following participation in the Ed+gineering Project through frequency counts and exemplar quotes for Collaborations (Collab) 1 and 2. 


\section{RQ3: PSTs' and UESs' overall perceptions}

PSTs in both collaborations indicated an increase in their understanding of the work of engineers and engineering as a field (see Table III). PSTs and UESs earlier in the program (Collaboration 1) reported changes in their perceptions of engineers and in the field of engineering more often than participants in Collaboration 2. Both PSTs and UESs shared positive perceptions of teamwork through the project and benefits of working through multidisciplinary collaborations. There were several students who reported challenges to teamwork during the semester, but realized they were able to develop strategies to enhance their teamwork strategies in this professional skill area. Students overwhelmingly reported positive affective responses to teaching, engineering, science, and the overall project. This is especially true in PSTs' response to teaching [engineering] as important and their comfort with engineering. 
TABLE III

PERCEPTIONS OF ENGINEERS \& FIELD OF ENGINEERING, PERCEIVED CHANGE IN ACADEMIC/PROFESSIONAL SKILLS, \& AFFECTIVE RESPONSES

\begin{tabular}{|c|c|c|c|}
\hline Theme & $\begin{array}{r}\text { Th } \\
\text { Freq } \\
\text { (tot: } \\
\text { inst: }\end{array}$ & $\begin{array}{l}\text { lency } \\
\text { l\# of } \\
\text { nces) }\end{array}$ & $\begin{array}{c}\text { Dominant Sub-Themes } \\
\text { (if applicable) } \\
\text { Frequencies }(n=\# \text { of coded instances) and Exemplar Quotes }\end{array}$ \\
\hline RQ3-Collab 1 & PSTs & UESs & \multirow[b]{2}{*}{$\begin{array}{l}\text { Fields of Engineering } \\
\text { PST: } n=10 ; \text { Before this project, I knew that Engineering was basically creating solutions } \\
\text { to problems by building things. After the project, I have learned that there are several } \\
\text { fields of Engineering and it is not just building things. Some fields of Engineering include } \\
\text { Mechanical, Civil, Chemical, and even Software. Each discipline of Engineering focuses } \\
\text { on different problems and different solutions. For example, a Software Engineer may } \\
\text { work on computers and chips where a Mechanical Engineer may be in charge of } \\
\text { buildings, cars, and other objects. } \\
\text { UES: } n=0 ; \text { n/a } \\
\text { Conceptions of Engineers \& Engineering } \\
\text { PST: } n=35 ; \text { I understand now that engineering is more hands-on than I thought, and it is } \\
\text { a group effort. I used to think engineering was a single person activity that was behind a } \\
\text { desk as their career. I now understand that those are all of the things that engineering } \\
\text { isn't. } \\
\text { UES: } n=10 ; \text { I learned that failure is part of the engineering process and critical thinking } \\
\text { can be demonstrated in the smallest areas of experiments. }\end{array}$} \\
\hline $\begin{array}{l}\text { Perceptions of } \\
\text { Engineers \& Fields of } \\
\text { Engineering }\end{array}$ & 45 & 10 & \\
\hline
\end{tabular}




\begin{tabular}{|c|c|c|c|}
\hline $\begin{array}{l}\text { Perceptions of Change } \\
\text { in Academic \& } \\
\text { Professional Skills }\end{array}$ & 31 & 27 & $\begin{array}{l}\text { Teamwork } \\
\text { PST: } n=27 ; \text { Working with other people can sometimes be stressful but I found that } \\
\text { having a group that I could rely on gave me confidence while completing assignments, } \\
\text { and performing the actual lesson. } \\
\text { UES: } n=19 ; \text { Groups in engineering projects are crucial to get the best outcome. } \\
\text { Preparation for Professional Tasks } \\
\text { PST: } n=0 ; \mathrm{n} / \mathrm{a} \\
\text { UES: } n=4 ; \text { What was valuable about this experience was being able to be a teacher for } \\
\text { an hour and conquering my fear of speaking in front of people just a little more than I } \\
\text { could before. } \\
\text { Multidisciplinary Focus } \\
\text { PST: } \mathrm{n}=4 ; \text { The value of this experience was the fact that it allowed me to team up with } \\
\text { others who are in a completely separate field of study from my own. } \\
\text { UES: } \mathrm{n}=4 ; \text { I was also able to get experience on working with non-engineers, which } \\
\text { forced me to think about certain engineering topics completely differently. }\end{array}$ \\
\hline Affective Responses & 55 & 17 & $\begin{array}{l}\text { Teaching Importance (Importance, Interest, \& Confidence) } \\
\text { - Positive } \\
\text { PST: } n=11 ; \text { "Being able to work with students was very valuable to me. I was able to } \\
\text { work with students just like I want to in just a few short years." } \\
\text { UES: } n=4 ; \text { "Teaching the students was probably the most valuable experience for me. It } \\
\text { was challenging though because we had to simplify the concepts a lot." } \\
\text { • Negative } \\
\text { PST: } n=0 ; \text { n/a } \\
\text { UES: } n=4 ; \text { "As for teaching, I learned that I do not want to do this as a career, as I felt } \\
\text { way over my head with some of the teaching concepts." } \\
\text { Science Concepts (Importance, Interest, Confidence, Still Unsure, Intimidated) } \\
\text { • Positive } \\
\text { PST: } n=0 ; n / a \\
\text { UES: } n=0 ; n / a \\
\text { - Negative } \\
\text { PST: } n=0 ; n / a \\
\text { UES: } n=0 ; n / a\end{array}$ \\
\hline
\end{tabular}




\begin{tabular}{|c|c|c|c|}
\hline & & & $\begin{array}{l}\text { Engineering (Importance, Interest, Confidence, Intimidating, Complicated) } \\
\text { - Positive } \\
\text { PST: } n=23 ; \text { Before this lesson I would have seen engineering as something I would } \\
\text { never be able to understand or grasp. I was very surprised to see how much engineering } \\
\text { goes into our life that we don't even think about. I would not think of it as a boring topic } \\
\text { to learn about after we did this presentation.....I now understand that engineers play a } \\
\text { more vital role than I ever would have thought } \\
\text { UES: } n=0 ; \text { n/a } \\
\text { - Negative } \\
\text { PST: } n=11 ; \text { There so many different branches of engineering that I had never heard of } \\
\text { before, each one sounding more complicated, and intimidating then the last. } \\
\text { UES: } n=0 ; \text { n/a } \\
\text { Overall Project } \\
\text { - Positive } \\
\text { PST: } n=6 ; \text { I believe there was a lot of value in this experience. I was able to have first } \\
\text { hand experience as the teacher of my own class. I think it was eye opening and taught me } \\
\text { a lot of important skills for the future } \\
\text { UES: } n=3 ; \text { The experience I gained from the project was the most valuable from it all. } \\
\text { That and meeting some of my peers that have my similar interests, including the } \\
\text { education students. } \\
\text { - Negative } \\
\text { PST: } n=4 ; \text { I think that this could have been a very valuable experience, I think that it is a } \\
\text { really great idea, but I do not feel that it was executed well. Part of this comes from my } \\
\text { overall dissatisfaction with my team. } \\
\text { UES: } n=6 ; \text { This experience was extremely valuable...it made me think on the fly a lot. }\end{array}$ \\
\hline RQ3-Collab 2 & PSTs & UESs & \multirow{2}{*}{$\begin{array}{l}\text { Fields of Engineering } \\
\text { PST: } n=9 ; \text { I learned there are various types of engineers and each one is important. I } \\
\text { learned that a Civil Engineer builds things like roads and buildings. Electrical Engineers } \\
\text { work with outlets and switches and the Mechanical Engineers work on things like engines } \\
\text { on a car. }\end{array}$} \\
\hline $\begin{array}{l}\text { Perceptions of } \\
\text { Engineers \& Fields of } \\
\text { Engineering }\end{array}$ & 31 & 8 & \\
\hline
\end{tabular}




\begin{tabular}{|c|c|c|c|}
\hline & & & $\begin{array}{l}\text { UES: } n=1 ; \text { I learned that there are even more types of engineering than I thought } \\
\text { before. } \\
\text { Conceptions of Engineers \& Engineering } \\
\text { PST: } n=18 ; \text { Before I started working with these engineering students, I never really } \\
\text { knew of any friends or family that classified themselves as "engineers" so I didn't have } \\
\text { any idea what that meant. To my knowledge, engineers where extremely smart, like a } \\
\text { perfect balance between mathematicians and scientists. I honestly thought that engineers } \\
\text { were either super skilled handymen (on the lowest scale) or scientists from NASA (on the } \\
\text { highest scale). } \\
\text { UES: } n=0 ; \mathrm{n} / \mathrm{a} \\
\text { No Change } \\
\text { PST: } n=4 ; \text { I have the same view of engineering as a field, I believe it's hard and takes } \\
\text { times to understand everything. I knew that they build things, create blueprints, fix things, } \\
\text { etc. } \\
\text { UES: } n=4 ; \text { I didn't learn anything new about engineering just reinforced topics I already } \\
\text { knew. }\end{array}$ \\
\hline $\begin{array}{l}\text { Perceptions of Change } \\
\text { in Academic \& } \\
\text { Professional Skills }\end{array}$ & 35 & 21 & $\begin{array}{l}\text { Teamwork } \\
\text { PST: } n=10 ; \text { I learned that you are not always going to like the people that you work } \\
\text { with, but it is important that you put that aside to reach your goal for the group. } \\
\text { UES: } n=1 ; \text { The project forced us to use good group-work skills, especially since we were } \\
\text { working alongside students who were not in the same class or even in the same major. It } \\
\text { can be easy to forget sometimes that not everyone will have the same knowledge we do. } \\
\text { Positive Perception } \\
\text { PST: } n=13 ; \text { As for working with other people, I learned that it is important to listen and } \\
\text { communicate well. I also learned that just because people have different interests it is } \\
\text { possible to share things in common and have fun together. } \\
\text { UES: } n=15 ; \text { I learned how to work with a good team and how to lead well. Leading } \\
\text { doesn't always mean you have all the answers." } \\
\text { - Negative Perception } \\
\text { PST: } n=3 ; \text { What I learned from working with other people is that you are never going to } \\
\text { get along with everybody and also that not everyone is going to pull their weight. }\end{array}$ \\
\hline
\end{tabular}




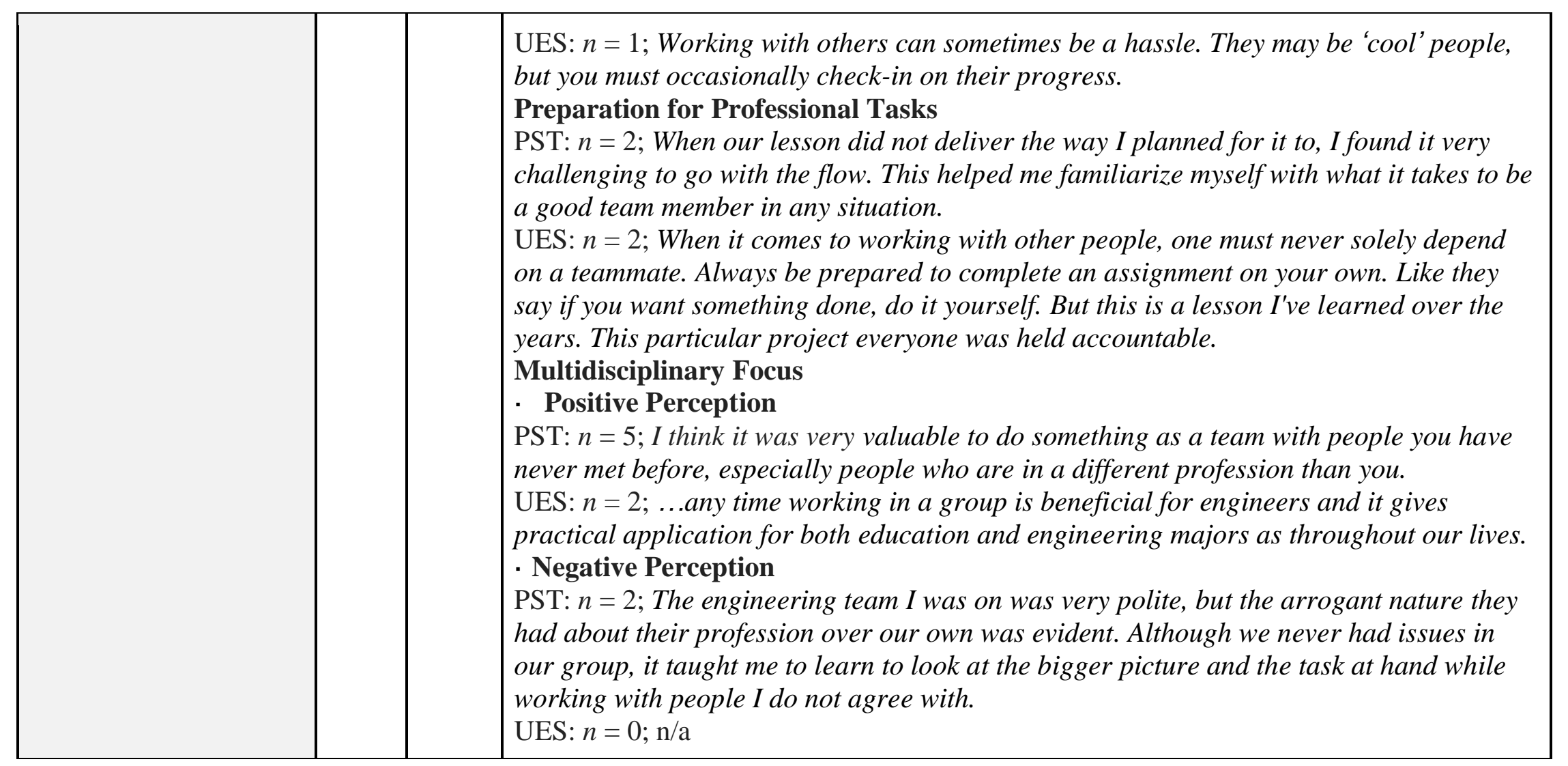




\begin{tabular}{|c|c|c|c|}
\hline Affective Responses & 47 & 30 & 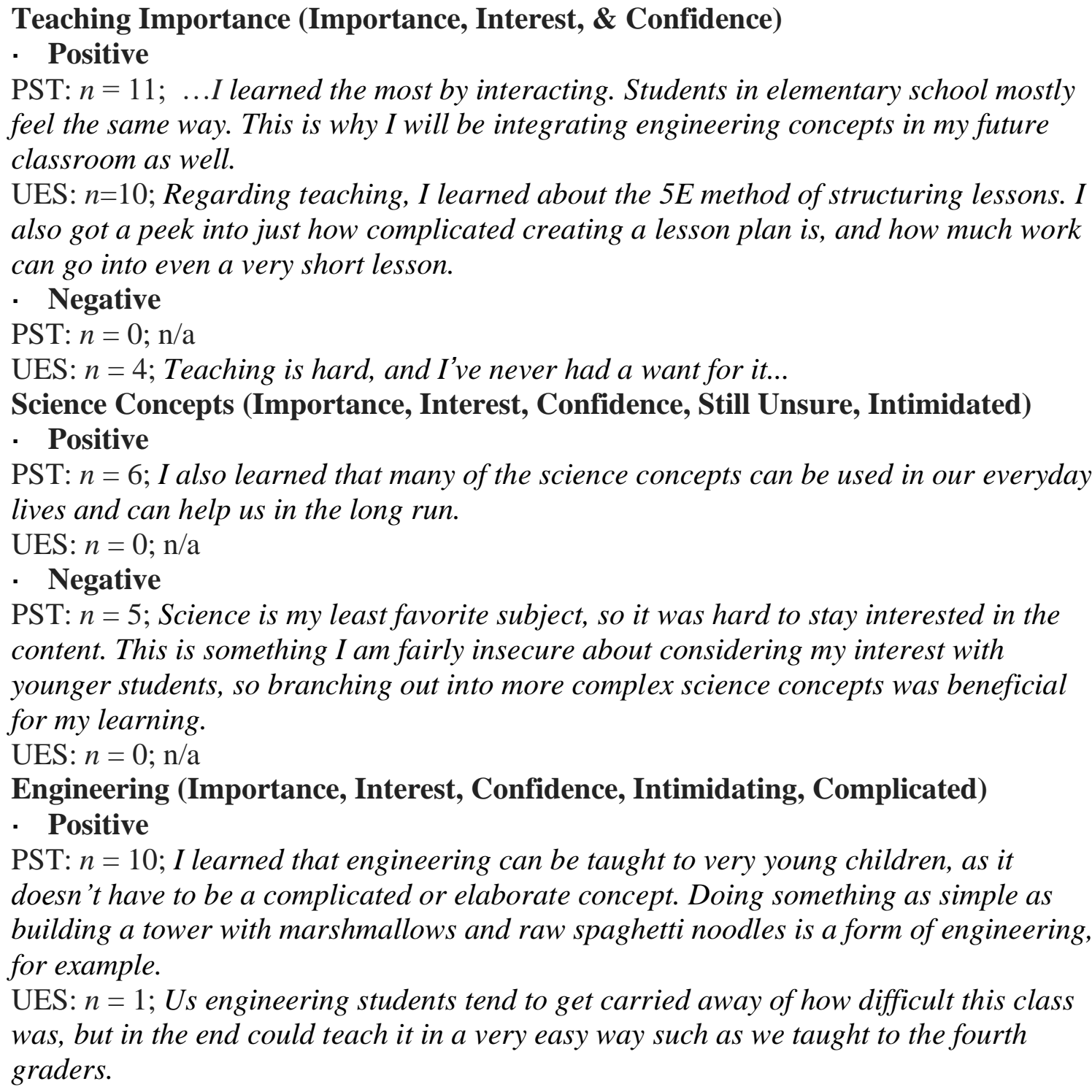 \\
\hline
\end{tabular}




\begin{tabular}{|l|l|}
\hline 1 & $\begin{array}{l}\text { Negative } \\
\text { PST: } n=2 ; \text { I learned new topics in engineering and how it is a very complicated subject. } \\
\text { UES: } n=0 ; \text { n/a } \\
\text { Overall Project } \\
\text { Positive } \\
\text { PST: } n=9 ; \text { This experience was valuable in many ways. It required I step out of my } \\
\text { comfort zone, it commanded that I employ every aspect of my expertise as a student and a } \\
\text { teacher, and it tested what kind of person I really was. } \\
\text { UES: } n=14 ; \text { I thought the interaction with the kids to see how young minds are in } \\
\text { comparison to where we are today in our studies is great, it gives you a perspective on } \\
\text { how far you have come. } \\
\text { Negative } \\
\text { PST: } n=4 ; \text { It was challenging in many ways in regard to coordinating the whole of the } \\
\text { lesson while managing so many other tasks simultaneously. } \\
\text { UES: } n=1 ; \text { To me as an engineering student I see the value the education students and } \\
\text { the kids get from the lesson however I do not think we get anything out of the project, } \\
\text { besides refining teamwork skills. Having to dumb down the topics presented did not help } \\
\text { us better understand fluid mechanics. }\end{array}$ \\
\hline
\end{tabular}

Table III provides exemplars of the perceptions of engineers \& fields of engineering, perceived change in academic/professional skills, and affective responses to the Ed+gineering Project through frequency counts and exemplar quotes for Collaborations (Collab) 1 and 2. 


\section{Conclusions and Implications}

The PSTs were more aware and comfortable with the engineering field following lesson development and delivery, even explaining particular science/engineering concepts. PSTs in Collaboration 1 demonstrated a less sophisticated level of understanding of the EDP than their engineering student partners, but it may not be realistic for education students to be fully proficient in the EDP after only one intervention. The EDP is a way of thinking, and not a predetermined route that must be strictly followed. Engineers possess a working knowledge of the EDP, but this knowledge is often not explicitly taught to engineering students, nor tested in a formal manner. Preliminary paired $t$-tests indicated that PSTs in Collaboration 2 (science methods) gained significant science content knowledge overall, and in specific constructs (e.g., viscosity, energy/friction, conservation of energy/friction, drag \& lift) following Ed+gineering experience. Both PSTs and UESs, but especially the latter, came to realize the importance of planning and preparing lessons to be taught to an audience. UESs reported greater appreciation for the work of educators, helping reduce the societally-embedded elitist perception of careers in engineering fields as compared to those in education.

PSTs and UESs expressed how they learned to work in groups with multidisciplinary members - this is a valuable lesson for their respective professional careers. Further, the UESs were exposed to interacting with children, which is a skill that many employers who value outreach will appreciate. The partnership also provided opportunities for UESs to cultivate pedagogical skills, which may prove valuable for presenting new ideas to people, in outreach capacities with partnering educators, or if they end up in a faculty position in academia. Overall, the project was positively viewed by students.

Following encouraging results from this preliminary work, the project team believes the Ed+gineering model can make a scholarly contribution to the field through the improvement of team formation and team-building strategies for students across disparate majors. The multidisciplinary collaboration model will also provide insight for similarly designed projects and research teams at the post-secondary level. Moving forward, the research team will continue to track students' content and pedagogical gains, while concurrently monitoring retention and persistence of engineering students through their programs as a result of participating in the Ed+gineering experience. 


\section{References}

[1] L. Y. Santiago and R. A. Hensel, "Engineering attrition and university retention," In Proc. ASEE Annu. Conf. Expo, (pp. 10-13), June 2012.

[2] Accreditation Board for Engineering and Technology [ABET], Criteria for Accrediting Engineering Programs. Retrieved from https://www.abet.org/wpcontent/uploads/2018/11/E001-19-20-EAC-Criteria-11-24-18.pdf.

[3] R. J. Brouwer, "Integrating service learning into a first-year engineering Course," In FIE'99 Frontiers in Education. 29th Annual Frontiers in Education Conference. Designing the Future of Science and Engineering Education. Conference Proceedings, November 1999, IEEE Cat. No. 99CH37011, Vol. 1, pp. 12A6-13.

[4] K. Falkner and D. S. Munro, "Easing the transition: a collaborative learning Approach." In Proceedings of the Eleventh Australasian Conference on Computing Education, January 2009, Volume 95, pp. 65-74.

[5] J. Duffy, L. Barrington, and M. Heredia, "Recruitment, Retention, and Service Learning in Engineering," In Proceedings of the American Society for Engineering Education 2011 Annual Conference, Vancouver, CA, 2011.

[6] L. Barrington and J. Duffy, "Maximizing Benefits of Service-Learning in Engineering," Proceedings of the American Society for Engineering Education 2010 Annual Conference, Louisville, Kentucky, 2010.

[7] Next generation science standards: For states, by states. NGSS Lead States, Washington, D.C.: The National Academies Press, 2013.

[8] K. B. Wendell, "Design Practices of Preservice Elementary Teachers in an Integrated Engineering and Literature Experience," Journal of Pre-College Engineering Education Research, 4(2), pp. 29-46, 2014.

[9] R. Steinberg, Y. Wyner, G. Borman, and I. I. Salame, "Targeted courses in inquiry science for future elementary school teachers," Journal of College Science Teaching, 44(6), pp. 51-56, 2015.

[10] R. W. Bybee, “Advancing STEM education: A 2020 vision,” Technology and Engineering Teacher, 70(1), pp. 30-35, 2010. 
[11] M. C. Hsu, S. Purzer, and M. E. Cardella, "Elementary teachers' views about teaching design, engineering, and technology," Journal of Pre-College Engineering Education Research (J-PEER), 1(2), 5, pp. 31-39, 2011.

[12] R. J. Rich, B. Jones, O. Belikov, E. Yoshikawa, and M. Perkins, "Computing and engineering in elementary school: The effect of year-long training on elementary teacher self-efficacy and beliefs about teaching computing and engineering," Online Submission, 1(1), 2017.

[13] M. Bers and M. Portsmore, "Teaching partnerships: Early childhood and engineering students teaching math and science through robotics," Journal of Science Education and Technology, 14(1), pp. 59-73, 2005.

[14] P. M. Rowell, B. J. Gustafson, and S. M. Guilbert, "Engineers in elementary classrooms: Perceptions of learning to solve technological problems," Research in Science \& Technological Education, 17(1), pp. 109-118, 1999.

[15] J. Piaget, The equilibration of cognitive structures: The central problem of intellectual development. University of Chicago Press, 1985.

[16] L. S. Vygotsky, Mind in society: The development of higher psychological processes. Harvard university press, 1980.

[17] D. Boud, R. Cohen, and J. Sampson, Peer learning in higher education: Learning from and with each other. Routledge, 2014.

[18] R. W. Bybee, J. A. Taylor, A. Gardner, P. Van Scotter, J. C. Powell, A. Westbrook, and N. Landes, The BSCS 5E instructional model: Origins and effectiveness. Colorado Springs, Co: BSCS, 5, 88-98, 2006.

[19] N. Magpili, P. Pazos, and P. S. Ullal, "A qualitative inquiry into the role of web-based collaboration tools and instructional scaffolds in the facilitation of team processes." Proceedings of the American Society of Engineering Education 2016 Annual Conference, New Orleans, 2016.

[20] M. C. Hsu, M. E. Cardella, and S. Purzer, "Elementary students' engineering design process knowledge: Instrument development and pilot test," In American Society for Engineering Education. American Society for Engineering Education, 2012. 